Patrycja Łanowy ${ }^{I}$, Miłosz Bichalski ${ }^{I}$, Krystian Ślusarz ${ }^{I}$, Weronika Pyka ${ }^{I}$, Jakub Dzindzio ${ }^{1}$, Maria Błaszkowskal, Barbara Oczko-Grzesik', Maciej Piasecki ${ }^{l}$, Jerzy Jaroszewicz'

\title{
ACTINOMYCOSIS - A FORGOTTEN CHRONIC INFECTIOUS DISEASE - CASE REPORT SERIES
}

\section{PROMIENICA - ZAPOMNIANA, PRZEWLEKŁA CHOROBA ZAKAŹNA - SERIA OPISÓW PRZYPADKÓW}

\author{
${ }^{1}$ Medical University of Silesia, Katowice, Poland, Department of Infectious Diseases and Hepatology \\ Śląski Uniwersytet Medyczny w Katowicach, Klinika Chorób Zakaźnych i Hepatologii
}

\begin{abstract}
Actinomycosis is one of the greatest 'chameleons' among infectious diseases. It may imitate inflammation, abscess or a neoplasmatic tumor. Moreover, correct diagnosis is even more challenging due to the fact that the disease takes on various forms like: cervicocephalic, abdominal, or affects the reproductive organs. In order to highlight the diagnostic difficulties of actinomycosis, we have decided to describe six cases of female patients (aged 31-73 years, mean age: 52 years) hospitalized due to actinomycosis in the Department of Infectious Diseases and Hepatology between 2014-2019. Additionally, a case of one patient was described in detail as the course of her disease was exceptionally non-specific. Only in 2 of 6 patients the primary diagnosis was correct. The four other patients were initially suspected with cancer or inflammation. Three of the patients were diagnosed with the abdominal form of actinomycosis, one - neck and head, and one presented both locations. Only histopathological examinations during invasive procedures allowed to state the final diagnosis. An adequate diagnosis was associated with a number of additional tests and delayed appropriate treatment. WBC and CRP were within normal range in all patients. Four patients completed treatment successfully after 60-192 days, one is still on therapy and one is lost to follow-up. In conclusion, common features of actinomycosis presented in this case series include predominance of female gender, abdominal localization and lack of typical symptoms. What is more, therapy with antibiotics, mainly doxycycline and beta-lactams resulted in complete regression of lesions in the majority of cases. Given the examples of our patients we believe that actinomycosis should be considered in the differential diagnosis of all abdominal tumors, especially in women.
\end{abstract}

Abbreviations: WBC - white blood cells, CRP - C-reactive protein, CT - computed tomography, IUD - IntraUterine Device, i.v. - intravenous.

Keywords: actinomycosis, actinomyces, abdominal tumor, antibiotic

\section{STRESZCZENIE}

Promienica to największy "kameleon" wśród chorób zakaźnych - może naśladować zapalenie, ropień, a nawet nowotwór. Postawienie prawidłowej diagnozy jest wymagające ze względu na fakt, że choroba ta występuje w wielu postaciach: twarzowo-szyjnej, brzusznej, bądź w obrębie miednicy mniejszej. W latach 2014 - 2019 w naszym Oddziale z powodu aktynomykozy hospitalizowano 6 pacjentek pomiędzy 31. a 72. r.ż.. Przypadek jednej z pacjentek jest opisany szczegółowo w niniejszej pracy ze względu na nietypowy przebieg choroby. Jedynie $\mathrm{u}$ dwóch $\mathrm{z}$ sześciu pacjentek pierwotna diagnoza była prawidłowa, natomiast u pozostałych czterech pacjentek początkowo podejrzewano nowotwór lub zmiany o charakterze zapalnym. $\mathrm{U}$ trzech pacjentek zdiagnozowano brzuszną postać promienicy, u jednej twarzowo-szyjną, natomiast u ostatniego zostały zdiagnozowane równolegle występujące postacie: brzuszna i twarzowo-szyjna. Jedynie badanie histopatologiczne, które może być przeprowadzone dzięki pobraniu materiału metodami inwazyjnymi, pozwala na jednoznaczne ustalenie diagnozy. Różnicowanie wymaga wykonania dodatkowych badań, co

(C) National Institute of Public Health - National Institute of Hygiene / Narodowy Instytut Zdrowia Publicznego - Państwowy Zakład Higieny 
opóźnia wprowadzenie odpowiedniego leczenia. Liczba białych krwinek we krwi oraz CRP były prawidłowe ubadanych pacjentek. Cztery pacjentki zakończyły leczenie z sukcesem po 60-192 dniach, jedna nadal jest leczona. Podsumowując, do wspólnych cech prezentowanych w pracy przypadków należy płeć żeńska, lokalizacja (jama brzuszna i narządy w jamie brzusznej) oraz brak objawów charakterystycznych pozwalających postawić jednoznaczną diagnozę. Antybiotykoterapia, głównie doksycykliną i beta-laktamami, przyniosła w większości przypadków całkowitą regresję zmian chorobowych. Po wczesnym postawieniu prawidłowej diagnozy pacjent może uniknąć inwazyjnych zabiegów operacyjnych. Biorąc pod uwagę przykłady naszych pacjentów, uważamy, że promienica powinna być rozważana w diagnostyce różnicowej wszystkich guzów brzucha, zwłaszcza u kobiet.

Skróty: WBC - liczba białych krwinek, CRP - białko C-reaktywne, CT - tomografia komputerowa, i.v. dożylnie.

Slowa kluczowe: promienica, aktynomykoza, guz w jamie brzusznej, antybiotykoterapia

\section{INTRODUCTION}

Actinomycosis is an uncommon, neglected disease caused by bacteria from the Actinobacteria family which belongs to the Actinomyces genus $(1,2)$. These gram-positive, mainly anaerobic, pigment-producing, non-spores-producing microorganisms grow optimally in the temperature between $30^{\circ} \mathrm{C}$ to $37^{\circ} \mathrm{C}$, which implies that primarily these pathogens are zoonotic (1, 3-5). Pathogenic to humans are: Actinomyces israeli, A. naeslundii, A. myeri, A. viscosus, A. odontolyticus (1). Infection caused by Actinomyces spp. is classified as an endogenous infection, due to the fact that some species are present in humans' physiological flora (commensals of the particular parts of the body like: the oral cavity, oropharynx, urogenital tract or gastrointestinal tract) $(1,6)$.

The colonization of the oral cavity with Actinomyces begins during infancy. A. odontolyticus, A. gerencseriae, A. viscosus, A. naeslundii may be isolated from the oral cavity mucosa during whole human's life. A. israeli which is recognized as the main cause of human Actinomycosis appears in the oral cavity relatively rarely (1). Also, an oral species of Actinomyces may be found in the tonsillar crypts (1). Actinomyces spp. such as A. myeri or A. radingae are commensals and reside on the mucosa of the gastrointestinal and the genitourinary tract $(1,2)$. What is interesting - some kinds of Actinomyces were isolated from the sputum samples from tuberculosis patients as a part of the microflora $(1,7)$. Transferred on the surface of foreign bodies or via traumatic damages of the mucosa - profound parts of tissues become available for Actinomyces (1). Actinomycosis is believed to be more frequent in male subjects. Interestingly, our case series, the largest in the literature, includes only female patients.

Early diagnosis is difficult due to non-specific symptoms, such as: oedma, mild fever, weight loss and others depending on the location. Chronic symp-

\section{WSTEP}

Aktynomykoza jest rzadką, często pomijaną w procesie diagnostyki, chorobą wywoływaną przez bakterie z typu Actinobacteria, do których należą bakterie $\mathrm{z}$ rodzaju Actinomyces $(1,2)$. Optymalna temperatura wzrostu tych Gram-dodatnich, głównie beztlenowych mikroorganizmów to $30^{\circ} \mathrm{C}-37^{\circ} \mathrm{C}$, co wskazuje na pierwotnie odzwierzęce pochodzenie tych patogenów (1, 3-5). Chorobotwórcze dla gatunku ludzkiego są: Actinomyces israeli, A. naeslundii, A. myeri, A. viscosus, $A$. odontolyticus (1). Zakażenie wywołane przez Actinomyces spp. klasyfikowane jest jako infekcja endogenna, ponieważ wybrane gatunki wchodzą w skład flory fizjologicznej określonych części ciała, takich jak jama ustna, gardło, układ moczowo-płciowy lub przewód pokarmowy $(1,6)$.

Kolonizacja jamy ustnej przez gatunki z rodzaju Actinomyces może zaczynać się już w okresie niemowlęcym. A. odontolyticus, A. gerencseriae, A. viscosus, A. naeslundii są izolowane ze śluzówki jamy ustnej w ciągu całego życia. A. israeli, która jest bakterią najczęściej identyfikowaną w przypadku zachorowań na promienicę, pojawia się w jamie ustnej stosunkowo rzadko. Gatunki zasiedlające jamę ustną można znaleźć również w kryptach migdałków (1). Gatunki Actinomyces, takie jak $A$. myeri czy $A$. radingae, są komensalami bytującymi na śluzówce przewodu pokarmowego oraz układu moczowo-płciowego $(1,2)$. Co ciekawe, niektóre gatunki Actinomyces jako część mikroflory izolowano z próbek plwociny u pacjentów chorych na gruźlicę $(1,7)$. Poprzez urazy uszkadzające błonę śluzową oraz wraz z ciałami obcymi, bakterie przedostają się do głębiej położonych tkanek. Uważa się, że na promienicę częściej chorują mężczyźni, a wczesna diagnostyka jest utrudniona w wyniku nieswoistych objawów choroby, do których mogą należeć: obrzęk tkanek, niewysoka gorączka, utrata masy ciała i inne zależne od lokalizacji. Przewlekłymi objawami są ropnie, ziarniniaki, zniszczenie tkanek 
toms include: abscesses, granulomas, tissue destruction, and extensive fibrosis. The bacteria spread to the adjacent soft and hard tissues. The primary mass of the tumor is light yellow as it contains sulfur grains. However, the characteristic grains are impossible to observe in lesions infiltrating some preexisting changes in a tissue, e.g. a lumpy lesion of lung cancer. Caries is a risk factor of the cervicofacial form of actinomycosis, in this case it is an endogenous infection, and it may occur after a tooth extraction or other dental procedures. What is more, aspiration of actinomycetes from the oral cavity may result in the development of actinomycosis - infiltrates are likely to appear in the chest wall, and the spine or ribs may be damaged. Abdominal actinomycosis often begins in the appendix and diverticula of the colon. Furthermore, the pelvic form may occur after using an intrauterine contraceptive device (IUD). Bacteraemia and hematogenous spread of the disease between the internal organs is very rare. Similarly, bone infiltration is extremely rare and it is exceptionally caused by the proximity of lesions in adjacent tissues. The lymphatic system is rarely affected, although there are reports describing actinomycosis of the lymph nodes (8). It is estimated that less than $10 \%$ of patients with actinomycosis are preoperatively correctly diagnosed, due to the symptomatology similar to other, much more common diseases such as: malignant tumors, tuberculosis or Crohn's disease $(4,9,10)$. Taking into account these significant diagnostic difficulties of the disease and in order to draw more attention to it, we have decided to present a series of cases of actinomycosis.

\section{CASE REPORTS}

The clinical characteristics and treatment results of six women hospitalized in the Department of Infectious Diseases and Hepatology due to actinomycosis, including the patient described below, are listed in a table. It characterizes some aspects such as: the patient's age, disease location, main symptoms, initial diagnosis, risk factors, and the duration and effectiveness of the antibiotic therapy. The abdominal form of actinomycosis dominated in the presented group, however in the literature it is considered less common than the cervical form. Two-thirds of the patients underwent surgery that could have had been avoided if the the correct diagnosis had been made earlier.

\section{Case report no.1}

A 46-years-old female patient turned to her GP due to low-grade fever and a palpable tumor in the mesogastrium area. Additionally, she reported that she had used an IUD several years before the symptoms appeared. As a result of the first medical consultation oraz rozległe zwłóknienia. Bakterie rozprzestrzeniają się na sąsiednie tkanki miękkie i twarde. Pierwotna masa guza ma kolor jasnożółty, gdyż występują w niej ziarna siarkowe, jednak niemożliwe są one do zaobserwowania w zmianach naciekających na występującą już wcześniej zmianę np. na zmianę guzowatą raka płuc. Próchnica jest czynnikiem ryzyka promienicy w postaci szyjno-twarzowej, wówczas choroba ma pochodzenie endogenne, a infekcja może nastąpić po usunięciu zęba lub innym zabiegu stomatologicznym. Aspiracja promieniowców z jamy ustnej może skutkować rozwinięciem promienicy piersiowej - nacieki pojawiają się w ścianie klatki piersiowej, a kręgosłup i żebra mogą ulegać zniszczeniu. Promienica brzuszna najczęściej rozpoczyna się w wyrostku robaczkowym oraz uchyłkach okrężnicy, a w miednicy mniejszej może występować u kobiet stosujących wewnątrzmaciczne spirale antykoncepcyjne. Wyjątkowo dochodzi do rozprzestrzeniania się choroby w narządach wewnętrznych drogą krwionośną, a zajęcie kości występuje niezwykle rzadko i jest spowodowane zmianami pochodzącymi z tkanek sąsiednich. Układ limfatyczny jest rzadko zaangażowany w proces chorobowy, aczkolwiek istnieją doniesienia wskazujące na promienicę węzłów chłonnych (8). Szacuje się, że poniżej 10\% pacjentów z promienicą brzuszną jest diagnozowanych przedoperacyjnie z powodu symptomatologii podobnej do innych powszechnych chorób, jak nowotwory złośliwe, gruźlica lub choroba Leśniowskiego-Crohna $(4,9,10)$. W związku z istotnymi trudnościami diagnostycznymi choroby oraz w celu zwrócenia na nią większej uwagi zdecydowaliśmy się na przedstawienie opisu serii przypadków promienicy.

\section{OPISY PRZYPADKÓW}

Charakterystyka kliniczna i wyniki leczenia sześciu kobiet hospitalizowanych w Oddziale Chorób Zakaźnych i Hepatologii z powodu promienicy, włącznie z pacjentką opisaną poniżej, są wymienione w tabeli. Scharakteryzowano w niej niektóre aspekty, takie jak wiek pacjentek, lokalizację choroby, główne objawy, wstępne rozpoznanie, czynniki ryzyka oraz czas trwania antybiotykoterapii i jej skuteczność. U przedstawionych pacjentek dominowała postać brzuszna promienicy, którą uznaje się za rzadszą niż postać szyjna. U dwóch trzecich wykonano zabieg chirurgiczny, którego można było uniknąć, gdyby prawidłowa diagnoza została postawiona wcześniej.

\section{Opis przypadku nr 1}

46-letnia pacjentka zgłosiła się do lekarza pierwszego kontaktu z powodu stanów podgorączkowych oraz wyczuwalnego guza $\mathrm{w}$ okolicy śródbrzusza. W wywiadzie podała, że na kilka lat przed wystąpie- 
the patient underwent computed tomography (CT) of the abdomen and pelvis, which presented:

- areas of inflammatory infiltration in soft tissues within the right abdominal quadrant;

- foci of inflammation in the liver parenchyma;

- slight enlargement of the retroperitoneal lymph nodes;

- enlarged and heterogeneous appendages.

A further gynecological consultation resulted in a laparotomy and removal of the changed ovary with the tumor and accompanying adhesions in the pelvic and abdominal cavity.

Postoperative histopathological examination did not indicate a clear character of the tumor, although it has been stated that ovarian cancer was the most likely etiology of the lesions. Re-examination of the postoperative material did not confirm these suspicion, changing the diagnosis into chronic inflammation and ovarian abscess. Interestingly, on that point the pathologists still strongly rejected the possibility of actinomycosis being the cause of the tumor. Due to the unclear histopathological results, liver biopsy was performed. Inflammatory tissue (mainly neutrophils and macrophages) was revealed in the biopsy specimens, which indicated the features of the organ's infectious infiltration. Additionally, a cervical smear was performed in which no pathogens, including Actinomyces, were found.

Due to the lack of unequivocal diagnosis and therefore effective treatment, the patient had been referred to the Department of Infectious Diseases and Hepatology with the suspicion of actinomycosis. From the first day of hospitalization, the patient was administered an antibiotic therapy (doxycycline i.v, ceftriaxone i.v). Furthermore, additional tests and consultations were performed to exclude other suspicions (mainly oncological). After the third histopathological examination of the postoperative specimen, the presence of neoplastic cells was excluded and the final diagnosis of actinomycosis was finally made.

The total intravenous therapy with doxycycline and ceftriaxone lasted 26 days. A control CT presented a withdrawal of changes in the pelvis. The patient continued treatment with doxycycline i.v with $0.9 \% \mathrm{NaCl}$ in an outpatient setting (another 4 months). In a series of ultrasound examinations, a gradual regression of inflammatory changes within the appendages, abdominal wall and liver were described. The total treatment duration was 126 days. After that time the patient was considered cured and has not reported relapse so far.

Actinomycosis should be considered in women with low-grade fever, a non-specific abdominal pain, palpable pathological masses in the abdomen and signs of inflammatory infiltrates in the CT. One should also be vigilant if the patient reports history of IUD use, niem objawów stosowała wkładkę wewnątrzmaciczną. U pacjentki wykonano tomografię komputerową brzucha i miednicy, która wykazała:

- Obszary nacieku zapalnego w tkankach miękkich w obrębie prawego kwadrantu jamy brzusznej;

- Ogniska zapalne w miąższu wątroby;

- Niewielkie powiększenie węzłów chłonnych przestrzeni zaotrzewnowej;

- Powiększone i niejednorodne przydatki.

Zdecydowano się na konsultację ginekologiczną, której rezultatem była decyzja o laparotomii oraz usunięciu chorobowo zmienionego jajnika wraz z guzem i zrostami mu towarzyszącymi $\mathrm{w}$ obrębie miednicy i jamy brzusznej. Badania histopatologiczne otrzymanych preparatów nie wskazały jednoznacznej przyczyny powstania guza, lecz postawiono diagnozę raka jajnika. Powtórne zbadanie preparatu nie potwierdziło tych podejrzeń, zmieniając rozpoznanie na przewlekłe zapalenie i ropień jajników, jednocześnie odrzucając promienicę jako przyczynę choroby.

$\mathrm{Z}$ powodu niejednoznacznego rozpoznania histopatologicznego, wykonano biopsję wątroby. W bioptatach ujawniono tkankę zapalną (głównie neutrofile i makrofagi), co wskazywało na cechy nacieku narządu. Dodatkowo wykonano wymaz z szyjki macicy, w którym nie znaleziono żadnych patogenów, w tym Actynomyces.

Ze względu na niemożność postawienia jednoznacznej diagnozy, pacjentkę skierowano do Oddziału Chorób Zakaźnych i Hepatologii, z podejrzeniem promienicy. Począwszy od pierwszego dnia hospitalizacji pacjentka poddana została antybiotykoterapii (doksycyklina i.v, ceftriakson i.v). Diagnostykę przeprowadzono w kierunku wykluczenia innych podejrzeń (głównie onkologicznych). Po trzecim badaniu histopatologicznym wycinka pobranego podczas operacji wykluczono obecność komórek nowotworowych i postawiono ostatecznie rozpoznanie promienicy.

Całkowita terapia dożylna doksacykliną i ceftriaksonem trwała 26 dni. Kontrolne badanie tomograficzne wskazywało na wycofywanie się zmian w obrębie miednicy. Postanowiono kontynuować leczenie pacjentki doksycykliną i.v wraz z $0,9 \% \mathrm{NaCl}$ w warunkach ambulatoryjnych (kolejne 4 miesiące). W serii badań USG otrzymywano stopniowy regres zmian zapalnych w obrębie przydatków, ściany jamy brzusznej oraz wątroby. Całkowity czas leczenia wyniósł 126 dni. Pacjentkę uznano za wyleczoną, nie zgłosiła dotychczas nawrotu choroby.

Promienicę należy rozważyć u kobiet $\mathrm{z}$ nietypowym bólem i dyskomfortem w okolicach brzucha, z towarzyszącym stanem podgorączkowym, które w badaniach TK mają cechy nacieku zapalnego. Należy także zachować dodatkową czujność, jeżeli w wywiadzie wystąpił okres stosowania wkładki wewnątrz- 


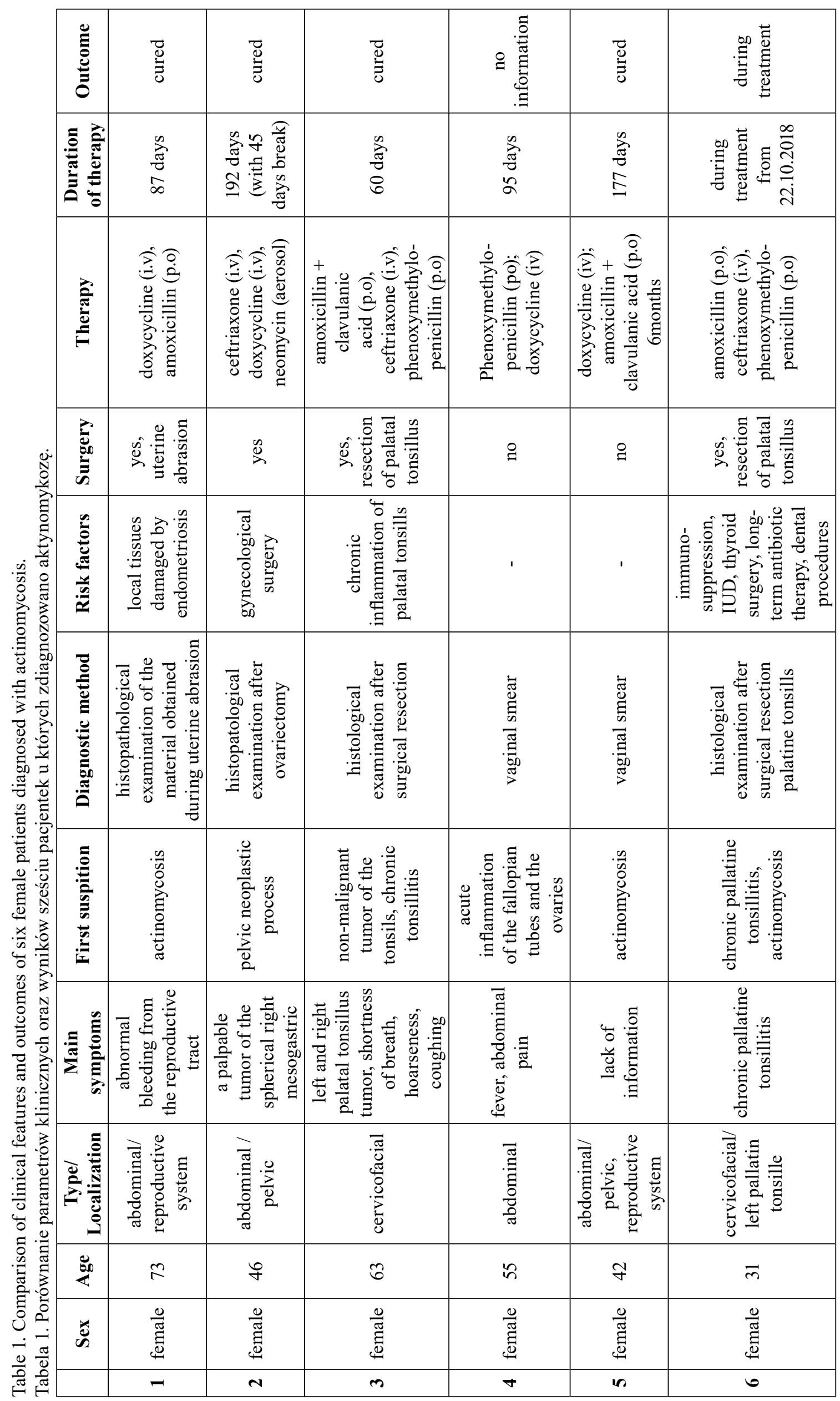


which is the most common risk factor for the development of actinomycosis in women.

\section{DISSCUSION}

Epidemiological data suggest that the incidence ratio of actinomycosis in male and female is 3:1 (11). However Pierre et al. presented a study in which the sex ratio was 1:1 (12). All patients in our case series were female which may suggest that greater attention considering actinomycosis should be paid to women.

Such difference in the frequency may result from the fact that women may be more careful about their health and do not neglect their sympthoms. Valor et al. showed that the age of patients varies and the age range for actinomycosis cannot be clearly defined (3). In our work the youngest patient was 31 years old and the oldest was 73 years old. It is worth noticing that several studies (13-15) highlight the fact that $60 \%$ cases of actinomycosis are the cervicofacial form of the disease. In our report, the predominant type is the abdominal type (4 of 6 cases), then the cervicofacial ( 2 of 6 cases). The pulmonary actinomycosis was not diagnosed in our group. The diagnostics of actinomycosis is very challenging, which may be indicated by non-characteristic symptoms, such as pain, fever or bleeding. However, there are cases in which even these symptoms do not occur (3).

Actinomycosis may also mimic malignant tumors - as confirmed not only by the case of our patient who was initially diagnosed with ovarian cancer $[16,17,18]$. The erroneously stated first diagnosis, which in our work concerned 2 out of 6 patients, may result in the implementation of invasive treatment. Currently, the recommendations for operative treatment of actinomycosis are limited in favor of the use of antibiotic therapy (1). It should be noted, that the correct diagnoses in our series of cases were based on various diagnostic methods. This indicates the lack of a specific test for this disease.

Furthermore, our patients' blood test results reveal that level of WBC was not deviating from normal. Only one patient had highly elevated CRP $(48 \mathrm{mg} / \mathrm{L})$. That data is different from the work of Valor et al. who proved that WBC and CRP in actinomycosis are higher than normal (3).

Nagao et al. recently published a case report of a 74-year-old man with esophageal cancer (19). In this case, the pulmonary form of actinomycosis was initially diagnosed as a metastasis of esophageal cancer or a recurrence of pulmonary adenocarcinoma five years after a radical thoracic surgery. At admission to the hospital, the patient did not report fever or any other symptoms. The normal temperature was one of macicznej, która jest najczęstszym czynnikiem ryzyka rozwoju promienicy brzucha i miednicy u kobiet.

\section{DYSKUSJA}

Dane epidemiologiczne wskazują, że częstość występowania promienicy u mężczyzn i kobiet wynosi 3:1 (11). Jednakże Pierre i wsp. przeprowadzili badanie, w którym ten stosunek wynosił 1:1 (12). Wszystkie opisywane przez nas przypadki dotyczyły pacjentów płci żeńskiej, co może sugerować, by większą uwagę w kontekście zachorowań na promienicę należy zwracać na kobiety. Taka zmiana tendencji zakażeń może wynikać z faktu większej dbałości i świadomości zdrowotnej kobiet. Valor i in. wykazali, że wiek zachorowania pacjentów jest różny, a główny przedział wiekowy infekcji nie może być jasno określony (3). W opisywanych przez nas przypadkach najmłodsza pacjentka miała 31 lat, a najstarsza 73 lata. Warto zauważyć, że w kilku badaniach (13-15) podkreślano fakt, że $60 \%$ przypadków promienicy to postać zlokalizowana $\mathrm{w}$ szyjce macicy. W naszej pracy dominującym typem jest typ brzuszny (4 z 6 przypadków), a następnie szyjno-twarzowy ( 2 z 6 przypadków). Nie odnotowano wystąpienia postaci płucnej. Diagnostyka promienicy jest bardzo trudna ze względu na niecharakterystyczne objawy, takie jak ból, gorączka lub krwawienie. Opisywane są jednak przypadki, w których nawet takie objawy nie występują (3).

Promienica może także naśladować nowotwory złośliwe (16-18), co potwierdza przypadek naszej pacjentki, u której początkowo zdiagnozowano nowotwór jajnika. Błędnie postawiona pierwsza diagnoza, która dotyczyła 2 z 6 pacjentek, może skutkować wdrożeniem leczenia inwazyjnego. Obecnie zalecenia dotyczące inwazyjnego leczenia promienicy są ograniczone na korzyść stosowania antybiotykoterapii (1). Należy zauważyć, że prawidłowe diagnozy w opisanej serii przypadków oparte były na różnych metodach diagnostycznych. Wskazuje to na brak pojedynczego, efektywnego testu diagnostycznego przypisanego tej chorobie. Wyniki badań krwi przedstawionych pacjentek wskazywały na prawidłową liczbę białych krwinek (WBC). Tylko jedna $\mathrm{z}$ pacjentek miała istotnie podwyższone białko C-reaktywne (CRP) - 48 $\mathrm{mg} / \mathrm{L}$. Dane te różnią się od pracy Valor i wsp. którzy wykazali, że wartości WBC i CRP są podwyższone u pacjentów z promienicą (3).

Nagao i wsp. niedawno opublikowali opis przypadku 74-letniego mężczyzny z rakiem przełyku (19), u którego płucną postać promienicy pierwotnie rozpoznano jako przerzut raka przełyku lub nawrót gruczolakoraka płucnego pięć lat po zabiegu operacyjnym. Przy przyjęciu do szpitala pacjent nie zgłaszał gorączki, ani 
the key factors that suggested the non-inflammatory nature of changes in the patient's lungs. The inflammatory parameters - as in the cases described by us - were normal or slightly elevated (WBC $10 \times 10^{3} / \mu \mathrm{L}$, CRP 6,07 mg/L). Interestingly, the patient's changes in the lungs were cured 6 months after the beginning of treatment (penicillin G i.v. and amoxicillin p.o.).

In our patients, penicillin and doxycycline was used to treat actinomycosis. Bonnefond et al. claim that no randomized controlled research evaluating antibiotic treatment regimens in actinomycosis were performed. The long-term antibiotic therapy is traditionally recommended on the basis of clinical experience $(4,20)$. The response to treatment is slow and in some cases presented in this manuscript it takes months to observe results. As mentioned before, invasive treatment should only be used in the most complicated cases (3). In our series of cases, $66,6 \%$ of women achieved full regression of the disease after average of 118 days antibiotic therapy.

\section{CONCLUSIONS}

In conclusion, common features of actinomycosis presented in this case series include predominance of female gender and abdominal localization. The lack of pathognomonic symptoms of actinomycosis and frequent mimicking other diseases, causes diagnostic and therapeutic difficulties. In the described cases the therapy with antybiotics, mainly doxycycline and beta-lactams, resulted in complete regression in the majority of cases. The presented data lead to the conclusion, that actinomycosis should be taken into consideration in the differential diagnosis of all abdominal and pelvic tumors, especially in women.

\section{REFERENCES}

1. Könönen E, Wade WG. Actinomyces and related organisms in human infections. Clin Microbiol Rev. 2015;28(2):419-42.

2. Jensen A, Fagö-Olsen $\mathrm{H}$, Sørensen $\mathrm{CH}$, et al.. Molecular mapping to species level of the tonsillar crypt microbiota associated with health and recurrent tonsillitis. PLoS One. 2013;8(2):e56418.

3. Valour F, Sénéchal A, Dupieux C, et al.. Actinomycosis: etiology, clinical features, diagnosis, treatment, and management. Infect Drug Resist. 2014;5(7):183-97.

4. Bonnefond S, Catroux M, Melenotte C, et al.. Clinical features of actinomycosis: A retrospective, multicenter study of 28 cases of miscellaneous presentations. Medicine

(Baltimore). 2016;95(24):e3923.

5. Moghimi M, Salentijn E, Debets-Ossenkop Y, et al.. Treatment of cervicofacial actinomycosis: żadnych innych objawów. Prawidłowa temperatura była jednym z kluczowych czynników przemawiających za niezapalnym charakterem zmian w płucach. Parametry zapalne - jak w opisanych przez nas przypadkach - były prawidłowe lub nieznacznie podwyższone (WBC $10 \times$ $10^{3} / \mu \mathrm{L}, \mathrm{CRP} 6,07 \mathrm{mg} / \mathrm{L}$ ). Zmiany w płucach ustąpiły 6 miesięcy po rozpoczęciu leczenia (penicylina $G$ i.v. i amoksycylina p.o.). U naszych pacjentów w leczeniu promienicy stosowano penicylinę i doksycyklinę. Bonnefond i wsp. wskazują na fakt, że żadne randomizowane kontrolowane badanie nie oceniało schematów leczenia antybiotykami w przypadku promienicy. Zasada długoterminowej antybiotykoterapii jest tradycyjnie zalecana na podstawie doświadczenia klinicznego $(4,20)$. Odpowiedź na leczenie jest powolna, a terapia może trwać miesiące - jak u niektórych opisywanych przez nas pacjentek. Operację należy stosować tylko w skomplikowanych przypadkach (3). W opisywanej serii przypadków u 66,6\% kobiet doszło do pełnej regresji choroby po średnim okresie 118 dni stosowania antybiotykoterapii.

\section{WNIOSKI}

W przedstawionej serii przypadków promienicy stwierdzono przewagę występowania u kobiet, dominacja postaci brzusznej oraz brak typowych objawów klinicznych infekcji. Brak objawów patognomonicznych dla aktynomykozy oraz częste naśladowanie przez nią innych chorób, m.in. nowotworowych stwarza poważne trudności diagnostyczne i terapeutyczne. W opisanych przypadkach antybiotykoterapia, głównie przy użyciu doksycykliny i antybiotyków beta-laktamowych przyniosła całkowite wycofanie się objawów choroby u większości pacjentek. Prezentowane dane skłaniają do wniosku, że promienica musi być brana pod uwagę $\mathrm{w}$ trakcie diagnostyki różnicowej guzów jamy brzusznej i miednicy mniejszej, szczególnie u kobiet.

a report of 19 cases and review of literature. Med Oral Patol Oral Cir Bucal. 2013;18(4):e627-32.

6. Jeffery-Smith A, Nic-Fhogartaigh C, Millar M. Is the Presence of Actinomyces spp. in Blood Culture Always Significant?. J Clin Microbiol. 2016;54(4):1137-1139.

7. Mehrotra N, Baidya A, Brijwal $M$, et al.. Actinomycosis of eye: Forgotten but not uncommon. Anaerobe. 2015;35(Pt B):1-2.

8. Sharma S, Valentino III DJ. Actinomycosis. StatPearls [Internet]. Treasure Island (FL): StatPearls Publishing; 2019 Jan-.

9. Pierre I, Zarrouk V, Noussair L, et al.. Invasive actinomycosis: surrogate marker of a poor 
prognosis in immunocompromised patients. Int $\mathbf{J}$ Infect Dis. 2014;29:74-9.

10. Wong VK, Turmezei TD, Weston VC. Actinomycosis. BMJ. 2011;343:d6099.

11. Smego RA Jr, Foglia G. Actinomycosis. Clin Infect Dis. 1998;26(6):1255-61.

12. Mandell GL, Bennett JE, Dolin R. Mandell, Douglas, and Bennett's Principles and Practice of Infectious Diseases. 7th ed. Philadelphia, PA: Churchill Livingstone Elsevier;2010.

13. Garner JP, Macdonald M, Kumar PK. Abdominal actinomycosis. Int J Surg. 2007;5(6):441-8.

14. Cintron JR, Del Pino A, Duarte B, et al.. Abdominal actinomycosis. Dis Colon Rectum 1996;39:105-8.

15. Chen YP, Chiang AJ, Chern CW, et al.. Actinomycosis mimicking an ovarian malignancy: Case report and literature review. Taiwan J Obstet Gynecol. 2016;55(5):766-767.

16. Karlowee V, Kolakshyapati M, Amatya VJ, et al.. Diffuse leptomeningeal glioneuronal tumor (DLGNT) mimicking Whipple's disease: a case report and literature review. Childs Nerv Syst. 2017;33(8):1411-1414.

17. Yang SS, Im YC. Severe abdominopelvic actinomycosis with colon perforation and hepatic involvement mimicking advanced sigmoid colon cancer with hepatic metastasis: a case study. BMC Surg. 2018;18(1):51.

18. Nagao M, Fukuda A, Matsumura T, et al.. Pulmonary actinomycosis mimicking a lung metastasis from esophageal cancer; a case report. BMC Pulm Med. 2018;18(1):39.

19. Park JY, Lee T, Lee H, et al.. Multivariate analysis of prognostic factors in patients with pulmonary actinomycosis. BMC Infect Dis. 2014;14:10.

Received: 18.11.2020

Accepted for publication: 26.02.2021

Otrzymano:18.11.2020 r.

Zaakceptowano do publikacji: 26.02.2021 r.

\section{Address for correspondence:}

Adres do korespondencji:

Dr hab. med. Jerzy Jaroszewicz,

Department of Infectious Diseases and Hepatology,

Medical University of Silesia in Katowice, ul. Aleja Legionów 49, 41-902 Bytom, Poland, e-mail: jjaroszewicz@sum.edu.pl, tel./fax: +48 32 281-92-45 